\title{
The role of policy makers and regulators in coopetition
}

Book or Report Section

Accepted Version

Mariani, M. (2018) The role of policy makers and regulators in coopetition. In: Fernandez, A.-S., Chiambaretto, P., Le Roy, F. and Czakon, W. (eds.) The Routledge companion to coopetition strategies. Routledge, Abingdon. ISBN 9781138736894 Available at http://centaur.reading.ac.uk/77798/

It is advisable to refer to the publisher's version if you intend to cite from the work. See Guidance on citing.

Publisher: Routledge

All outputs in CentAUR are protected by Intellectual Property Rights law, including copyright law. Copyright and IPR is retained by the creators or other copyright holders. Terms and conditions for use of this material are defined in the End User Agreement. 


\section{www.reading.ac.uk/centaur}

\section{CentAUR}

Central Archive at the University of Reading

Reading's research outputs online 


\title{
The role of policy makers and regulators in coopetition
}

\author{
Marcello Mariani \\ Henley Business School, University of Reading \\ Greenlands, Henley on Thames Oxfordshire, UK RG9 3AU \\ Tel: +44 (0)1491 418799 \\ email: m.mariani@henley.ac.uk \\ Chapter accepted for publication in \\ The Routledge companion to coopetition strategy \\ Anne Sophie-Fernandez \\ Paul Chiambaretto \\ Wojciech Czakon \\ Frédéric Le Roy
}

\begin{abstract}
This chapter provides an overview of extant research revolving around the role of policy makers and regulators in driving and affecting coopetition. Based on selected research, we describe the relevance of policy makers and regulators in triggering, promoting, and affecting coopetitive interactions among economic actors that did not intentionally plan to coopete before the external institutional stakeholders (i.e., a policy maker or regulator) created the conditions for the emergence of coopetititon. Several conclusions are drawn and a promising research agenda is put forward.
\end{abstract}

\section{Introduction}

Nowadays economic actors (individuals and organizations) are confronted with unprecedented levels of uncertainty and complexity stemming from an increasingly fast-changing and turbulent global environment. To address both uncertainty and complexity, they might decide to simultaneously compete and cooperate thus engaging in a paradoxical relationship wherein "regardless of whether they are in horizontal or vertical relationships, [they are] simultaneously involved in cooperative and competitive interactions." (Bengtsson \& Kock, 2014: p. 182).

The simultaneous pursuit of cooperation and competition, termed as co-opetition (Brandenburger \& Nalebuff, 1996; Brandenburger \& Stuart, 1996), is a challenging endeavour which brings entrepreneurs and firms to juxtapose conflicting interests and common interests, and deal with the resulting tensions (Bengsston \& Kock, 2014; Fernandez et al., 2014).

Management scholars in a number of different disciplinary fields (including strategy, marketing, innovation management, supply chain management, operations, etc.) are closely studying coopetition, its multifaceted manifestations and related issues in a number of different empirical settings and by leveraging a variety of theoretical lenses and methodological approaches. Accordingly, recent systematic literature reviews have shown an exponential growth in the number of management scientific works pertaining to coopetition (Bengtsson et al., 2013; Czakon et al., 2014).

So far, a relatively limited amount of studies has dealt with how coopetition and coopetitive interactions are triggered, inhibited and affected by external institutional stakeholders (for a review see Bengtsson \& Raza-Ullah, 2016). Among those, an even smaller part has addressed the role of policy makers and regulators in triggering and affecting coopetitive interactios. To this aim, this 
chapter is intended as a critical synthesis of selected research around the role played by policy makers and regulators in affecting coopetition. The overview, far from being a comprehensive literature review, builds mainly on the author's previous extensive work on the topic and on other relevant contributions. In the ensuing section, we provide a demarcation of the drivers of coopetition, with a focus on external drivers and especially external stakeholders. We enrich this discussion with a reflection on aspects related to intentionality vs. unintentionality of the focal coopeting actors when policy makers or regulators shape an institutional environment that can promote, hinder or generally affect coopetition. In section three, we review the studies that have mostly dealt with the role of policy makers and regulators in triggering and affecting coopetition, and discuss and re-elaborate critically their findings in view of roles played and desired objectives. In the fourth section, we draw several conclusions and reflect on what we currently know (and do not know) about the role of policy makers and regulators in coopetition.

\section{The role of intentionality and external stakeholders in driving coopetition}

\subsection{Intentional and unintended strategies}

Strategy and strategizing can be either intentional or unintentional. While the mainstream strategy literature is concerned mostly with deliberate strategies, a minority of contributions have emphasized and theorized that the process of strategy formation can be characterized in some instances by a relative lack of intentionality (Mintzberg 1978; Mintzberg \& McHugh 1985; Mintzberg \& Waters 1982). In the footsteps of Mintzberg, strategy can be defined as "a pattern in a stream of decisions" (1978, 935). Accordingly, strategies can be at first sight clustered into two main groups: deliberate strategies (i.e., strategies might be realized more or less as previously intended) on one hand and emergent strategies (i.e., strategies might be realized differently and despite ex-ante intentions) on the other hand (Mintzberg \& Waters 1985). In theory, a perfectly emergent strategy implies that there must be "order in the absence of intention" about it (Mintzberg \& Waters 1985: 2). However, the assumptions behind the perfectly emergent and perfectly deliberate strategies appear extreme and somehow rare, thus suggesting that both the purely emergent and deliberate strategies are the conceptual extremes of a continuum along which real strategies typically fall (Mintzberg \& Waters 1985: 270).

In most of the literature dealing with coopetition, the units of analysis are typically the actors involved in the coopetitive relationship (focal co-opeting actors) and there is an underlying assumption that coopetition is somehow deliberately planned by the co-opeting actors due to the risks involved in cooperating with a competitor (Pellegrin-Boucher et al., 2013; Tidström, 2008).

However, in many real world contexts, there are external factors (i.e., political, social, economic and technological factors) and stakeholders (i.e., policy makers and regulators) that might set the scene for how economic actors engage in coopetitive interactions during the formation and the development stages of the strategy lifecycle. In certain situations, the very same rules of the game could be modified by regulatory changes (Czakon \& Rogalski, 2014; Depeyre \& Dumez 2009; Mariani, 2007), over which individual economic actors have little or no control.

More specifically, a particular subset of external stakeholders, namely policy makers and regulatory agencies in an industry, can introduce new rules or modify the existing ones, thus affecting the way economic actors engage and coopete with each other. In other terms, coopetition is not always and necessarily a by-product of the choice of an economic agent (be it an entrepreneur or a firm), but might be an unintended and unintentional outcome (desired or not) of mandates of external institutional stakeholders (DiMaggio \& Powell, 1983).

Until 2007, coopetition studies have not sufficiently addressed the aspect of intentionality. The strong assumption was (and still is in many mainstream coopetitive analyses) that economic actors engaging in coopetitive interactions act always intentionally (Dagnino \& Mariani, 2010). However, this is not necessarily the case especially when external stakeholders such as policy makers and regulators induce an unintended strategic process that contributes to establish coopetitive ties 
among economic actors. For instance, the regulators can influence the institutional environment that might in its turn trigger, inhibit or affect coopetition.

In general, when coopetition is intentional, it can be because of external and/or internal drivers. Similarly, when coopetition is unintentional, it could be because of external and/or internal drivers. In the ensuing paragraph, we will succinctly describe the drivers of coopetition, with a focus on external drivers and more specifically external stakeholders.

\subsection{Drivers of coopetition: a focus on external drivers}

In the footsteps of Bengtsson and Raza-Ullah (2016) we can distinguish three partly overlapping categories of coopetition drivers: internal, relation-specific and external. Internal drivers include firms' goals, resources and capabilities. Relation-specific drivers include partner features and relationship characteristics. External drivers encompass influential stakeholders, industrial features, and technological demands. For a complete and updated account of the articles dealing with internal, relation-specific and external factors we refer to Bengtsson and Raza-Ullah (2016).

In what follows we focus on a few studies related to internal and external drivers with an emphasis on external ones. Internal drivers encompass internal goals and capabilities, perceived vulnerability and prospective strategies. They relate to organizational resources and capabilities (Gnyawali \& Park, 2009), strategies (Luo, 2007), past experience coopeting together (Mariani, 2016), and motives related to improvement of performance (M'Chirgui, 2005). For instance, Gnyawali and Park (2009) underline that for competing SMEs it might be beneficial to cooperate because they can pool resources and capabilities to develop similar technologies in the same market. Luo (2007) suggests that cooperating with rivals might be a suitable strategy to penetrate into new markets. Mariani (2016) points out that past experience of collaboration and co-opetition might induce even more coopetition. Based on a study of the smart card industry, M'Chirgui (2005) finds that coopetition can be driven by the quest for better performance.

External drivers include environmental conditions such as technological demand (Bengtsson \& Johansson, 2014; Bouncken \& Kraus, 2013; Dai, 2008), industrial characteristics (Chen, 2014; Dowling et al., 1996; Ritala, 2012) and external stakeholders (Castaldo et al., 2010; Depeyre and Dumez, 2009; Ho \& Ganesan, 2013; Mariani, 2007, Wang et al., 2010). Technological uncertainty and complexity have been found to be possible precursors of coopetitive relatiosnhips (Bouncken \& Kraus, 2013; Dai, 2008) very much like the fact that different firms from different industries have to progressively integrate their technological capabilities and skills to develop new technologies (Bengtsson \& Johansson, 2014). Coopetitive interactions are influenced also by industrial characteristics including concentration and degree of regulation (Dowling et al., 1996), growth rates and level (Chen, 2014) and instability (Ritala, 2012). External stakeholders such as policy makers, regulators, independent mediators, interlocking directorates and buyers can play a major role in coopetition formation and development. For instance, in the opera sector policy makers can trigger coopetition among previously cooperating organisations (Mariani, 2007). In the US defence industry, regulators such as antitrust authorities have been found to play an architectural role, by setting the rules governing the arrangements, interconnections and interdependences of coopeting actors (Depeyre \& Dumez, 2009). Mediators are relevant in vertical coopetition (Castaldo et al., 2009) where companies such as ACNielsen can link and separate coopeting actors (in this case the supplier and the retailers) for the benefit of a project. Policies granting public subsidies can shape coopetition as well (Wang et al., 2010). Coopetition between firms is driven also by interlocking directorates serving multiple corporate boards in a focal industry (Simoni \& Caiazza, 2012). In a number of cases, strong buyers can generate a cooperative attitude among competing firms (Ho \& Ganesan, 2013) especially when they operate in a monopsony (Depeyre \& Dumez, 2009). In the following section, we review a selected number of coopetition studies dealing with the roles and objectives of a subset of external stakeholders able to trigger and affect coopetitive interactions: policy makers and regulators. 


\section{Policy makers and regulators and their roles and objectives in coopetition interactions}

Policy makers and regulators are a particular subset of external stakeholders that have been studied with a certain degree of depth so far in coopetition literature. They are typically governmental public bodies external to inter-firm relationships typically without a profit motive. They can mandate higher or lower level of competition/cooperation than the status quo to pursue the following objectives:

1) avoid the formation of trusts, cartels, oligopolies, monopolies, collusion;

2) prevent a decline in firms' customer orientation;

3) rationalize public expenditure and streamline public subsidies;

4) ensure assets complementarity and the use of other firms' capabilities.

In what follows we synthesize the findings of selected research in the four aforementioned situations with a focus on how firms and organisations in the industry typically adhere to the rules set up by the policy makers and regulators often before forming any coopetitive strategy. Afterwards they might shape coopetitive strategies that are not intentional but emergent.

\subsection{Avoiding the formation of trusts, cartels, oligopolies, monopolies, collusion}

Policy makers and regulators might be concerned with a few industry characteristics such as concentration and might want to limit the formation of trusts, cartels, oligopolies and monopolies through the introduction and enforcement of antitrust regulations or other rules. In this case, they will try to deter tacit or explicit collusion (Ouchi \& Bolton, 1988; Telser, 1985; Williamson, 1985). Consequently, firms that were cooperating might be forced to increasingly compete and this could lead to the formation or modification of new/existing coopetitive interactions.

Depeyre and Dumez (2009) study the role played by the US Defense regulators on the formation and modifications of coopetitive interactions over a forty years' time span. They argue that both the US Defence department and regulators (i.e. antitrust authorities) have contributed to shape the fabric of the industry architecture, by setting the rules governing the coopetitive interconnections of the production firms supplying weapons to the US Defense industry. They show that the regulators of the industry have affected coopetitive interactions between weapon suppliers at different moments in time by reducing the influence of the only customer (i.e., the Department of Defence (DoD)) operating since 1989 in a situation of monopsony.

They describe that over the period 1989-1999, competition between the military forces was dissolved as they were merged into a single monopsony under the DoD; moreover, the number of suppliers were reduced to two for every weapon systems (i.e., fighters, submarines, bombers, etc.). In exchange, the government promised to support financially the reorganisation that led to a wave of mergers and acquisitions. However, the M\&A wave was ended in 1998 when the Antitrust Division of the Department of Justice prohibited the acquisition of Northrop Grumman by Lockheed Martin. This regulatory decision had structural effects: the new antitrust rules pushed many SMEs to quit the market that was left in the hands of several big vertically integrated primes (i.e., the winners of a tender). The DoD enforced a winner take all rule among a very limited amount of primes and allied suppliers selected through a competitive process. Moreover, it oversaw that the tenders could be won by all of the (few) competing firms to avoid favouring collusive practices and a monopoly. However, firms had to cooperate as no prime could deal with the development of all the weapons subsystems. In the end, the DoD had encouraged concentration among a few big suppliers, vertically integrated, and highly specialised (Boeing, Lockheed Martin, etc.). Regarding the regulatory authorities they influenced coopetitive interactions also from a behavioural point of view as they imposed 'firewalls' minimising vertical cooperation within firms and generating vertical cooperation with competitors, to maintain horizontal competition. This state of affairs, due to the structural change triggered by the antitrust authority has been named by the authors "structural complementarity coopetition" (p. 141).

Overall, the case illustrated by Depeyre and Dumez (2009) investigates the interplay between policy makers in the defence industry and anti-trust regulators in influencing structural conditions and firms' behaviour regarding coopetitive interactions. Their findings clearly point to the idea that 
policy makers and regulators can drive and affect coopetition by laying down rules and enforcing them at different moments in time thus not only triggering coopetition but also affecting its evolution over time.

Interestingly, the activities of regulatory authorities and policy makers could lead to unexpected consequences. For instance, Czakon and Rogalski (2014) offer empirical evidence that coopetition might be emergent rather than deliberate. Based on an in depth study of the Polish energy trade market, they investigate the motives and rationale for companies to enter into coopetition. Among the findings, they highlight that coopetition might be the consequence of changes of demand or the reaction to regulatory inducements. More specifically, since the reference regulator in the Polish electricity trade market is concerned about the formation of tacit of explicit collusion, its role is to promote coopetition that paradoxically and unintendedly forces competitors to collaborate with each other thus creating the preconditions for coopetition.

\subsection{Preventing a decline in firms' customer orientation}

In situations of collusion (tacit or explicit), it has been shown that colluding firms might increase their profitability at the expense of customer orientation.

Rindfleisch and Moorman (2003) conduct a longitudinal study on competitor-dominated firm alliances and control for the presence of third parties such as antitrust authorities functioning as watchdog organisations, making sure that markets operators do not engage in anticompetitive practices. They found that coopeting firms operating in a context where a government agency is monitoring them experienced structurally no descrease in customer orientation over the three-year study period, whereas firms operating in a context without such a watchdog organization recorded a sharp decrease over the same period.

The authors interpret their findings based on neoclassical economics speculations that competitordominated firm alliances might not damage customers if they are governed by a monitoring system of their activities and enforcement against anticompetitive practices. This is the reason why the inclusion of a neutral third party, such as a government agency is seen as an effective solution against tacit or explicit collusion (Ouchi \& Bolton, 1988; Teece, 1992; Telser, 1985; Williamson, 1985). In practice, this is the reason why governmental bodies such as the US Department of Justice (DoJ) have rendered most forms of horizontal cooperation in the aforementioned alliances subject to a high level of scrutiny if not illegal. Moreover, in some instances the monitoring party can be deployed as a facilitator or a neutral judge to help solve disagreements and help build trust among companies (Scott, 2000).

\subsection{Rationalizing public expenditure and streamlining public subsidies}

Policy makers and regulators might be willing to rationalize an industry where the public sector is directing a substantial amount of financial resources (e.g., the defense industry, the publicly supported cultural sector, the national air transportation industry, the energy industry). By imposing higher levels of cooperation, policy makers and regulators might trigger coopetition among firms that were previously merely competing or might bring a shift in extant coopetitive interactions to cooperationdominated coopetition.

For instance, Mariani (2007) conducts a longitudinal empirical investigation on a consortium of nearby opera companies in Italy and analyses how imposed inter-competitor cooperation is triggered and evolves over time. The case describes the key role of the Tuscany region policy maker in triggering, through the imposition of cooperation, the emergence of inter competitor cooperation among the three Italian opera houses of Livorno, Lucca, and Pisa. The multiple case study is deployed to introduce the brand new concept of induced coopetition that can be described as "the transitory initiation stage of a coopetitive strategy life cycle where cooperation is imposed on competing 
organizations, and 'emergentness' prevails on (and anticipates) 'deliberateness'.” (Mariani, 2007: p. 117).

The qualifying elements of induced coopetition are the imposition of cooperation on behalf of the policy maker and the incremental adoption of organizational solutions and stratagems (e.g., a common scenery set, a shared orchestra, etc.) enabling the creation of actual interfaces among competing organizations' value chains. Interestingly the process is described as incremental in the sense that cooperation could originally happen on an individual activity, a portion of an activity, or even a single project, and then be extended to other activities and projects thus commending one or more reconfigurations of the division of labor within the inter-organizational value chain (Porter, 1985). In their turn, incremental changes might prompt strategic learning based on activities and processes, which in turn can potentially stimulate additional activity-based (Johnson et al., 2003; Whittington, 1996) cooperative strategies that can develop and consolidate trust among partners and support business processes reengineering within the interorganizational value chain.

The coopetitive attitudes of Italian opera companies are compared with those of other companies in Australia (Mariani, 2009) and Germany (Mariani, 2008) to find that cultural policymakers at different levels of government (federal, state, regional, city-state) are trying to impose cooperation between publicly subsidized opera houses with the aim of rationalising the opera productions on offer and obtaining better value for taxpayers' money. These top-down interventions carried out by the policy makers improved coordination among the individual opera houses involved, minimising costs and gradually triggering something similar to a collective strategy (Astley \& Fombrun 1983). Induced coopetition was therefore found to be relevant also in the German context. Interestingly, in all the performing arts context analysed, the policy maker was able to infuse fresh ideas able to minimize the dangers of overlapping knowledge and projects across organisations (Rindfleisch \& Moorman, 2003).

By borrowing the concept of unintentional coopetition from Mariani (2007), Kylänen and Rusko (2011) study the Pyha-Luosto tourism destination (Finnish Lapland) and emphasize the formation of unintentional co-opetitive interactions as the by-product of geographic proximity, colocation and micro clusters as well as the role of public and semi-public organizations. Especially they distinguish between two groups of organizations: those interested in strategic long-term development of the destinations (such as provinces, Destination Marketing Organizations, municipality, and larger firms) and those interested in the operational short-term profitability of the destinations (such as small firms and workers).

Based on a matrix matching the strategic dimension on one hand and the operational dimension on the other (see Figure 1), they come up with two situations where unintentional coopetition occurs: 1) when strategic level cooperation (cooperation going on between the province, DMO, municipality and larger firms) turns out to be competition in the operational level; 2) when strategic level competition turns out to be cooperation in the operational level.

Figure 1 - Different forms of intentional and unintentional coopetition in the context of interaction between strategic level and operational level viewpoints

\begin{tabular}{|c|c|c|c|c|}
\hline \multicolumn{5}{|c|}{ Strategic level (level of province, DMO, municipalities and the larger firms in the case; a longer time-frame) } \\
\hline & & Cooperation & Coopetition & Competition \\
\hline \multirow[t]{3}{*}{$\begin{array}{l}\text { Operational level (level } \\
\text { of single smaller firms or } \\
\text { workers in the case; a } \\
\text { shorter time-frame) }\end{array}$} & Cooperation & I Intentional cooperation & $\begin{array}{l}\text { II Cooperation based } \\
\text { coopetition }\end{array}$ & $\begin{array}{l}\text { III Unintentional coopetition: } \\
\text { strategic level competition } \\
\text { turns out to be cooperation in } \\
\text { operational level }\end{array}$ \\
\hline & Coopetition & $\begin{array}{l}\text { IV Cooperation based } \\
\text { coopetition }\end{array}$ & $\begin{array}{l}\text { V Intentional } \\
\text { coopetition }\end{array}$ & $\begin{array}{l}\text { VI Competition based } \\
\text { coopetition }\end{array}$ \\
\hline & Competition & $\begin{array}{l}\text { VII Unintentional coopetition: } \\
\text { strategic level cooperation } \\
\text { turns out to be competition in } \\
\text { operational level }\end{array}$ & $\begin{array}{l}\text { VIII Competition based } \\
\text { coopetition }\end{array}$ & IX Intentional competition \\
\hline
\end{tabular}

Source: (Kylanen and Rusko, 2011) 
Overall Kylänen and Rusko (2011) confirm the findings of Mariani (2007, 2009) that public sector organizations might exert a very important effect in the way coopetition is formed and actually can change the "center of gravity" between competition and cooperation.

Mariani (2007, 2008, 2009) and Kylanen and Rusko (2011), highlight that changes triggered by external institutional stakeholders can generate learning opportunities for the actors involved in coopetitive interactions. For instance, Mariani (2009) underlines that induced coopetition is able to enhance strategic learning since it might activate cognitive processes leading managers to revise their mental models as they are forced to think about alternative ways of designing and managing inter-organisational value chains, by implementing acti vity-based cooperation and forms of business process re-engineering.

While trust has been found to be a critical determinant for coopetition in the tourism sector (Czakon \& Czernek, 2016), certainly the role of local policy makers in supporting collaboration between co-located highly interdependent competing tourism firms has been emphasized extensively (Kylänen \& Mariani, 2012, 2014a, 2014b; Mariani, 2016; Wang \& Krakover, 2008).

Rationalisation objectives for policy makers have been found to play a major role not only in the cultural sector, but also in sectors as diverse as the defense and the travel and tourism one. In their longitudinal study, Depeyre and Dumez (2009) illustrate that during the cold war period the customers (i.e., the Navy, Air Force, Army, etc.) selected a prime (i.e., the winner of the tender) and second-tier suppliers through a competitive process and imposed vertical cooperation between the prime and the second-tier suppliers. The latter ones were often competitors of the former ones in other tenders and therefore coopetition emerged as a by-product of a governmental department's decisions that allowed regulating the competitive processes. This first stage, labelled "imposed coopetition", was intended to improve the rationalisation of a heavily publicly funded industry.

In their work on the Northern Italian tourism sector, Mariani and Giorgio (2017) found a strong trend of rationalization of subsidies for Destination Management Organizations (DMOs) and tourism firms geographically close to each other and/or part of the same administrative area to attract tourist flows, increase tourism expenditure and promote investments in the area. This allowed especially DMOs to pool and rationalise financial and non-financial resources to rebrand a wider region subsuming smaller areas.

\subsection{Ensuring assets complementarity and the use of other firms' capabilities}

In their work on the Polish energy sector, Czakon and Rogalski (2014) identify a second reason why companies start to coopete: the need to rationalize the activities by ensuring assets complementarity and use other firms' competencies through outsourcing.

Depeyre and Dumez (2009) note that in the third stage of the development of the US Defence industry (after 1999), a major watershed event took place: the advent and consolidation of complex networkcentric systems that demanded a strategic competitive mindset. More specifically, the complexity of weapon production transformed the production process into a system of systems that could be managed only by very few firms that needed to shape alliances with each other to deliver the final output. The firm that managed to become the prime in this new situation has to demonstrate that its alliance with competitors could generate the production results and secured a monopolistic relationship with the DoD for a long time, getting likely a sustainable competitive advantage leveraging path- dependency and lock- in. 


\section{Conclusions: what we know and we don't know about coopetition driven by policy makers and regulators}

In this concluding section we summarize what we know and what we would like to know about coopetition driven and affected by policy makers and regulators, recognizing that what we would like to know represents itself a challenging research agenda to work on in the near future.

Today we know that external stakeholders such as policy makers can not only set the scene for coopetitive interactions but they can actually trigger coopetition and affect it once it has been formed. In many cases an external stakeholder (for instance a policy maker or a regulatory agency) can mandate (higher levels of) cooperation or competition thus paving the way for the formation of coopetitive interactions. As this situation was not deliberately planned ex-ante by the co-opeting actors, clearly those actors have entered unintentionally coopetition, in some cases ultimately embracing induced coopetition (Mariani, 2007, 2008, 2009).

Unintentional coopetition can generate learning processes leading managers to revise their cognitive models as they would need to think about different ways of designing inter-organizational value chains through the implementation of activity-based cooperation and forms of business process re-engineering.

Imposed coopetition can lead to a more effective distribution of tasks among coopetitive partners as demonstrated by Depeyre and Dumez (2009) in the defence industry, Czakon and Rogalski (2014) in the energy industry, Mariani $(2007,2008,2009)$ in the publicly subsidised cultural sector, and Kylanen and Rusko (2011), Czakon and Cernek (2016) and Mariani (2016) in the tourism sector. Regardless of the specific mechanisms through which policy makers and regulators might trigger the formation of a coopetitive relationship, it is worthwhile noticing that at any given time the change of the rules might affect the coopetitive interactions and either strengthen or weaken the cooperative/competitive component that allows a coopetitive interaction to exist. Overall, external stakeholders such as policy makers and regulators could intervene at different stages of a coopetitive strategy lifecycle and might thus influence how economic actors (i.e., entrepreneurs and companies) coopete other over time (Czakon, 2013; Depeyre \& Dumez, 2009; Kylänen \& Mariani, 2012, 2014a, 2014b; Mariani \& Kylänen, 2014; Mariani, 2007, 2009; Mariani, 2016; Mariani \& Giorgio, 2017).

While this is what we know at the moment of writing, much still remains on the table for further investigation. First, while policy makers' driven coopetition has been found to trigger learning processes, it has been hypothesized that strategic learning arising in an induced-coopetition context might be different from that taking place in a competitive or cooperative situation (Mariani, 2007, 2009). This hypothesis needs certainly further empirical validation and testing. Second and related to the former point, it has been suggested that the coopetitive actors' enacted environment (Pfeffer \& Salancick 1978) could significantly change, thus triggering an intense modification in managerial mental models. Also this aspect needs more empirical substantiation and might be further developed and validated with studies on other industries and contexts. Third, it would be relevant to refine the conceptualization of a specific subset of external stakeholders such as policy makers and regulators in coopetitive settings and track them over time in different empirical contexts, sectors, and industries. Fourth and related to the former point, most of extant research has focused on the implementation phase, while the aspect of how policy makers and regulators behave once coopetition has formed is somehow neglected. Consequently, it would be valuable to bridge this gap in order to understand if and to what extent policy makers and regulators help coopetitors manage their tensions.

From a methodological point of view several advancements seems necessary. First, coopetition strategy scholar should device appropriate methods to study how policy makers and regulators can drive coopetition. Often it is rather complicated to determine if coopetition (and induced/imposed coopetition in particular) is simply dictated by a single external stakeholder's intervention or adds to other conjoint external environmental factors. Second and related to the first point, methods should be devised to disentangle the individual contribution of one external stakeholder form the cumulative contribution of two or more third parties to the initiation and development of a coopetitive relationship. Third, a process perspective might help address the role of 
policy makers and regulators in triggering and affecting coopetition changes over time. In the studies of Mariani (2007) and Depeyre and Dumez (2009) the architectural roles of the regulators and policy makers respond to changing environmental conditions (e.g., political, economic and social conditions) that are translated into new or revised rules that affect how firms and organisations interact with each other and coopete. Accordingly, more emphasis should be given to a diachronic approach to the understanding of coopetition mandated or affected by policy makers and regulators with an emphasis on longitudinal studies. Last, as already claimed by Mariani $(2007,2009)$ there is a need to shift the attention to the processes of coopetitive strategy formation, maintenance and dissolution. This might be undertaken by embracing a theory of change (Dahl, 2014), and its related methods (Van de Ven \& Poole, 2005); certainly this theoretical perspective and related methods might add value to extant longitudinal analysis and perhaps shed light on several aspects that still are underexplored.

\section{REFERENCES}

Bengtsson, M., Johansson, M., Näsholm, M., \& Raza-Ullah, T. (2013). A systematic review of coopetition, levels and effects at different levels. 13th EURAM Conference, Istanbul, Turkey, June 26-29.

Bengtsson, M., \& Kock, S. (2014). Coopetition - quo Vadis? Past accomplishments and future challenges. Industrial marketing management, 43(2), 180-188.

Bengtsson, M., Eriksson, J., \& Wincent, J. (2010b). Co-opetition dynamics - an outline for further inquiry. Competitiveness Review, 20(2), 194-214.

Bengtsson, M., Eriksson, J. \& Wincent, L. (2010a). New ideas for a new paradigm. In S. Yami, S. Castaldo, G.B. Dagnino, \& F. Le Roy (Eds.), Coopetition: Winning strategies for the 21st century (pp. 19-39). Cheltenham: Edward Elgar.

Bengtsson, M., \& Kock, S. (2000). Coopetition in Business Networks - To Cooperate and Compete Simultaneously. Industrial Marketing Management, 29(5), 411-425.

Bengtsson, M. \& Kock, S. (1999). Cooperation and competition in relationships between competitors in business networks. Journal of Business and Industrial Marketing, 14, 178-190.

Brandenburger, A.M., \& Nalebuff, B.J. (1996). Co-opetition. New York: Doubleday.

Brandenburger, A.M., \& Stuart, S. (1996). Value-based business strategy. Journal of Economical Management Strategy, 5(1), 5-14.

Castaldo, S., Möellering, G., Grosso, M., \& Zerbini F. (2010). Exploring how third-party organizations facilitate co-opetition management in buyer-seller relationships. In S. Yami, S. Castaldo, G.B. Dagnino, \& F. Le Roy (Eds.), Coopetition: Winning strategies for the 21st century (pp. 141-165). Cheltenham: Edward Elgar.

Czakon, W., \& Czernek, K. (2016). The role of trust-building mechanisms in entering into network coopetition: The case of tourism networks in Poland. Industrial Marketing Management, 57, 64-74.

Czakon, W. Mucha-Kuś, K. Rogalski, M. (2014). Coopetition research landscape - A Systematic literature review 1997-2010. Journal of Economics and Management, 17, 122-150.

Czakon, W. (2010). Emerging coopetition: an empirical investigation of coopetition as interorganizational relationship instability. In S. Yami, S. Castaldo, G.B. Dagnino, \& F. Le Roy (Eds.), Coopetition: Winning strategies for the 21st century (pp. 58-73). Cheltenham: Edward Elgar.

Dagnino, G.B., \& Mariani, M.M. (2010). Coopetitive Value Creation in Entrepreneurial Contexts: The Case of AlmaCube. In S. Yami, S. Castaldo, G.B. Dagnino, \& F. Le Roy (Eds.), Coopetition: Winning strategies for the 21 st century (pp. 101-123). Cheltenham: Edward Elgar.

Dahl, J., (2014). Conceptualizing coopetition as a process: An outline of change in cooperative and competitive interactions. Industrial Marketing Management, 43, 272-279.

Depeyre, C. \& Dumez, H. (2010). The role of architectural players in coopetition: the case of the US defense industry. In S. Yami, S. Castaldo, G.B. Dagnino, \& F. Le Roy (Eds.), Coopetition: Winning strategies for the 21 st century (pp. 124-140). Cheltenham: Edward Elgar.

DiMaggio, P.J., \& Powell, W.W. (1983). The Iron Cage Revisited: Institutional Isomorphism and Collective Rationality in Organizational Fields. American Sociological Review, 48(2), 147-16. 
Fernandez, A.S., Le Roy, F., \& Gnyawali, D.R. (2014). Sources and management of tension in co-opetition case evidence from telecommunications satellites manufacturing in Europe. Industrial Marketing Management, 43(2), 222-235.

Fjeldstad, Ø., Becerra, M., \& Narayananc, S. (2004). Strategic action in network industries: an empirical analysis of the European mobile phone industry. Scandinavian Journal of Management, 20(1-2), 173 196

Gnyawali, D.R., \& Park, B.J. (2009). Co-opetition and technological innovation in small and medium-sized enterprises: A multilevel conceptual model. Journal of Small Business Management, 47(3), 308-330.

Johnson, G., L. Melin, \& Whittington, R. (2003). Micro-Strategy and Strategizing. Towards an Activity-Based View. Journal of Management Studies, 40(1), 3-22.

Kylänen, M., \& Mariani, M. M., (2014b). Cooperative and coopetitive practices: Cases from the tourism industry. In M.M. Mariani, R. Baggio, D. Buhalis \& C. Longhi (Eds.), Tourism Management, Marketing and Development. Volume I: the Importance of Networks and ICTs (pp. 149-178). New York: Palgrave.

Kylänen, M., \& Mariani, M.M. (2014a). Unpacking the temporal dimension of coopetition in tourism destinations: evidence from Finnish and Italian theme parks. In R. Baggio, W. Czakon \& M. Mariani (Eds.), Managing Tourism in a Changing World: Issues and Cases (pp. 61-74). London: Routledge.

Kylänen, M., \& Mariani, M.M. (2012). Unpacking the temporal dimension of coopetition in tourism destinations: evidence from Finnish and Italian theme parks. Anatolia: An International Journal of Tourism and Hospitality Research, 23(1), 61-74.

Kylänen, M. \& Rusko, R. (2011). Unintentional coopetition in the service industries: the case of Pyha-Luosto tourism destination in the Finnish Lapland. European Management Journal, 29(3), 193-205.

Mariani, M.M, \& Giorgio, L. (2017). The "Pink Night" festival revisited: Meta-events and the role of destination partnerships in staging event tourism. Annals of Tourism Research, 62, 89-109.

Mariani, M. (2016). Coordination in inter-network co-opetition: evidence from the tourism sector, Industrial Marketing Management, 53, 103-123.

Mariani, M., \& Kylänen, M. (2014). The relevance of public-private partnerships in coopetition: Empirical evidence from the tourism sector. International Journal of Business Environment, 6(1), 106-125.

Mariani, M.M. (2009). Emergent coopetitive and cooperative strategies in inter-organizational relationships: empirical evidence from Australian and Italian operas. In G.B. Dagnino, \& E. Rocco (Eds.), Coopetition strategy. Theory, experiments and cases (pp. 166-190). London: Routledge.

Mariani, M.M. (2008). Induced Coopetition and Emergent Cooperation: An international Study on the Opera Houses Sector, Public, 15, 1-6.

Mariani, M.M., (2007). Coopetition as an emergent strategy: Empirical evidence from an Italian consortium of opera houses. International Studies of Management \& Organization, 37(2), 97-126.

Mintzberg, H. (1978). Patterns in Strategy Formation. Management Science, 24(9), 934-948.

Mintzberg, H., \& McHugh, H. (1985). Strategy Formation in Adhocracy. Administrative Science Quarterly, $30(2), 160-197$.

Mintzberg, H., \& Waters, W.J. (1982). Tracking Strategy in an Entrepreneurial Firm. Academy of Management Journal, 25 (3), 465-499.

Mintzberg, H., \& Waters, W.J. (1985). Of Strategies, Deliberate and Emergent. Strategic Management Journal, 6(3), 257-272.

Pellegrin-Boucher E., Le Roy F., Gurau C. (2013). Coopetitive strategies in the ICT sector: typology and stability. Technology Analysis \& Strategic Management, 25(1), 71-89.

Pfeffer, J., \& Salancick, G. (1978). The External Control of Organizations. New York: Harper \& Row.

Porter, M. (1985). Competitive Advantage. New York: Free Press.

Rindfleisch, A. \& Moorman, C. (2003). Interfirm Cooperation and Customer Orientation. Journal of Marketing Research, XL, 421-436.

Ritala,P. (2012). Coopetition strategy - when is it successful? Empirical evidence on innovation and market performance. British Journal of Management, 23(3), 307-324.

Tidström, A., (2008). Perspectives on coopetition on actor and operational levels. Management Research, 6(3), 207-217.

Wang, Y., \& Krakover, S. (2008). Destination marketing: competition, cooperation or coopetition?. International Journal of Contemporary Hospitality Management, 20(2), 126-141.

Whittington, R. (1996). Strategy as Practice. Long Range Planning, 29(5), 731-735. 